which perforate the latter. These tubes, which are open at the extremity, play the part of suckers, which pump in the fovilla and transmit it through the canals to the ovary. After fecundation, the perforated pollen becomes dried up, whilst the stigma becomes folded upon itself and withers.

Consequertly in the Gramineæ two principal phenomena occur, which are witnessed only in this family:-

1. The elongation and expulsion of the filaments of the stamens.

2. Fecundation by the perforation of the pollen.

These do not occur without reason.

The seed, the result of fecundation, must occupy when perfectly developed, the whole chamber formed by the union of the two valves. Now the stamens occupy two-thirds of this space, and by their volume they would obstruct the growth of the seed: they must be expelled; and hence the elongation of the filaments, and the existence and the utility of the alimentary glands.

As the fecundation is instantaneous, it is necessary that the fovilla should instantaneously penetrate to the ovary through the stigma, the existence of which only lasts during the moment of fecundation; hence the structure of the stigma, and the phenomenon of the perforation of the pollen.

All the facts that I have just indicated may be very easily observed in our cereals and the grasses of our meadows. To see the details of the fecundation, it is only necessary to split the outer valve longitudinally; by separating the two parts of this valve, we expose the organs of fecundation enclosed in the two curtains of the inner valve, and the warmth of the breath or a ray of the sun is sufficient to induce the phenomenon of fecundation.

The natural hybridization of the Gramineæ is impossible, from the exact closure of the space or chamber containing the organs of fecundation.-Comptes Rendus, June 21, 1869, tome lxviii. p. 1486.

\title{
On a Tree-Frog in New Granada which secretes a Poison employed by the Indians to poison their Arrows. By J. EscoBar.
}

This tree-frog appears to belong to the species called Phyllobates melanorhinus. It is known in the country by the names of Ranilla roja or rojiça. During life it is of a red tint shaded with Naples yellow, and consequently rather yellowish red, like certain oranges, the colour of which approaches that of the citron. The yellow predominates when the animal has been some time in alcohol. There are two varieties-one in which the belly is black, and another in which it is of the same colour as the upper parts.

The poison is furnished by the dorsal region. It does not appear to possess its properties completely unless it is collected at the moment when the animal, still living, secretes it. To cause its secretion, they introduce into the mouth of the frog a small wooden spatula, and, taking great precautions in order not to produce injuries which would cause death too rapidly, push it in so as to cause great suffering, under the influence of which the whole upper surface of the 
body becomes covered with a white, milky, and viscous liquid. This is the poison, with which the tips of the arrows are imbued as quickly as possible. Sometimes they obtain a greater quantity of this substance, if the animal has not succumbed under the first operation, by introducing a bodkin into one of the abdominal limbs, which induces a secretion of the same kind upon its surface. At other times, again, the same result is attained by exposing the frog to the moderate heat and the smoke of a clear fire*.

This poison can cause the death of large animals, such as the jaguar. It is likewise fatal to man.

Experiments tried upon animals seem to prove, like those made with curare, that the toxical action affects the organs of movement, and not those of sensibility. The drowsiness and sleep which precede the death of animals poisoned by the venom of toads were not observed.-Comptes Rendus, June 21, 1869, tome lxviii. p. 1488.

\section{An Hermaphrodite Nemertean from the Mediterranean. By A. F. Marion.}

Prof. W. Keferstein lately described (Archiv für Naturgeschichte, 1868), under the name of Borlasia hermaphroditica, a curious monœcious species, of which he only observed a single individual, at St. Malo in August 1867. This unexpected discovery has hitherto remained an isolated fact.

In March of the present year I discovered, on the coast of Marseilles, a new hermaphrodite Nemertean, which I have since obtained several times, always in full gestation. This species belongs to the genus Borlasia ; but it is distinct from the B.hermaphroditica of St. Malo, as is admitted by M. Keferstein himself, to whom I am happy to be able to dedicate it. Borlasia Kefersteinii lives at great depths, among the incrusted Algæ which usually shelter numerous Annelida of both the errant and sedentary forms.

Its body, which is very proteiform, attains a length of 15 millimetres when the animal is fully extended. It is covered with vibratile cilia, which are more numerous and longer in front round the aperture of the proboscis, and behind round the anal orifice. The head bears two pairs of eyes, furnished with a crystalline and a mass of black pigment. The proboscis is placed above the digestive tube, and seems sometimes to extend even to the lower extremity of the body. The anterior region of this organ is covered with tufts, which become interrupted and disappear a little below the stylus.

The male and female ovules are developed between the hepatic layer of the digestive tube and the walls of the body, in the usual manner. The female ovules, when completely developed, measure 0.317 millim., and consist of a vitelline membrane, a vitellus (which

* This last process has been indicated by M. Roulin as being employed by the Indians who wish to obtain from the Batrachians of the Choco the venom with which they poison their arrows (Revue des Deux Mondes, 1835, sér. 4. tome iv. p. 187). 


\section{$2 \mathrm{BHL}$ Biodiversity Heritage Library}

Escobar, J. 1869. "On a tree-frog in new granada which secretes a poison employed by the indians to poison their arrows." The Annals and magazine of natural history; zoology, botany, and geology 4, 135-136.

https://doi.org/10.1080/00222936908696016.

View This Item Online: $\underline{\text { https://www.biodiversitylibrary.org/item/88433 }}$

DOI: https://doi.org/10.1080/00222936908696016

Permalink: https://www.biodiversitylibrary.org/partpdf/65326

\section{Holding Institution}

Smithsonian Libraries

\section{Sponsored by}

Smithsonian

\section{Copyright \& Reuse}

Copyright Status: Public domain. The BHL considers that this work is no longer under copyright protection.

This document was created from content at the Biodiversity Heritage Library, the world's largest open access digital library for biodiversity literature and archives. Visit BHL at https://www.biodiversitylibrary.org. 